\title{
High-pressure Sodium Lighting Affects Greenhouse Production of Vegetative Cuttings for Specialty Annuals
}

\author{
Caroline S. Donnelly ${ }^{1}$ and Paul R. Fisher ${ }^{2}$ \\ Department of Plant Biology, University of New Hampshire, Durham, \\ NH 03824
}

Additional index words. Argyanthemum, Lantana, lemon verbena, liner, Heliotropium, New Guinea Impatiens, Osteospermum, Petunia, Scaevola, stock plant, supplemental light, Verbena

\begin{abstract}
The objective was to quantify the effect of supplemental lighting on cutting production for 10 herbaceous annual cultivars. Stock plants of four cultivars (Heliotropium arborescens 'Atlantis', Petunia 'Supertunia Sun Snow', Scaevola aemula 'New Wonder', and Verbena 'Tapien Soft Pink') received ambient light [average $6.2 \mathrm{~mol} \cdot \mathrm{m}^{-2} \cdot \mathrm{d}^{-1}$ photosynthetic photon flux (PPF) during the photoperiod], or ambient light plus either 1.6 or $2.8 \mathrm{~mol} \cdot \mathrm{m}^{-2} \cdot \mathrm{d}^{-1} P P F$ from high-pressure sodium (HPS) lamps for 11 hours. In a second experiment, the same four species plus six other cultivars were grown under ambient light (average $7.9 \mathrm{~mol} \cdot \mathrm{m}^{-2} \cdot \mathrm{d}^{-1} P P F$ ) or ambient plus $1.9 \mathrm{~mol} \cdot \mathrm{m}^{-2} \cdot \mathrm{d}^{-1} P P F$ from HPS. The effect of HPS on the production of cuttings varied greatly between species. Growth of Heliotropium was not significantly affected by light level in either experiment. In the first experiment, the addition of $1.6 \mathrm{~mol} \cdot \mathrm{m}^{-2} \cdot \mathrm{d}^{-1} P P F$ from HPS increased the number of Petunia 'Supertunia Sun Snow', Scaevola, and Verbena cuttings by $14 \%, 51 \%$, and $12 \%$. The addition of $2.8 \mathrm{~mol} \cdot \mathrm{m}^{-2} \cdot \mathrm{d}^{-1} P P F$ from HPS, increased cuttings harvested from these three species by $23 \%, 73 \%$, and $22 \%$ respectively. In the second experiment, Petunia 'Supertunia Sun Snow', Scaevola, Aloysia triphylla (lemon verbena), and Osteospermum 'Lemon Symphony' had a positive cutting production response to HPS (17\% to $45 \%$ increase), whereas cutting numbers of other species (Argyranthemum 'Summer Melody', Lantana 'Patriot Firewagon', Impatiens New Guinea hybrid 'Pedro', Petunia 'Supertunia Blue Wren', and Verbena) were not significantly affected by HPS. In both experiments, cutting quality (length, stem caliper, fresh mass, and dry mass) and subsequent rooting of cuttings were not significantly affected by light level.
\end{abstract}

Production of "specialty annuals" is a rapidly growing sector of the floriculture industry. Specialty annuals are vegetativelypropagated plants produced from cuttings or (less commonly) tissue culture. Cuttings are typically harvested from November to March from stock plants that were planted in July \& August. The cuttings are rooted in liner (i.e., plug) trays 4-6 weeks before finishing in 10$15-\mathrm{cm}$-diameter pots or as hanging baskets. Because of the cost of producing cuttings (labor, space, and time resources) and the high light demand for stock plant production, an increasing proportion of cuttings are produced in Central America, and are rooted in the United States. However, considerable numbers of cuttings continue to be produced in North America because of niche markets and concerns about availability or quality.

U.S. production of vegetative cuttings, particularly in northern areas, is limited by low ambient light levels during the winter months.

\footnotetext{
Received for publication 25 Sept. 2000. Accepted for publication 1 Oct. 2001. Scientific Contribution 2069 from the Univ. of New Hampshire Agricultural Experiment Station. We thank Michael Goyette, Henry and Jeff Huntington at Pleasant View Gardens, and PL Light Systems. for their financial and technical support of this project.

${ }^{1}$ MS Student.

${ }^{2}$ Assistant Professor.
}

In response, some growers have chosen to invest in supplemental lighting using highpressure sodium(HPS) lamps in order to increase photosynthetic rate.

Researchers have quantified the effect of supplemental lighting on cutting production for a limited number of floricultural species. Tsujita and Harney (1978) found that supplementing sunlight in a greenhouse with HPS at 100 $\mu \mathrm{mol} \cdot \mathrm{m}^{-2} \cdot \mathrm{s}^{-1}$ photosynthetically active radiation $(P A R)$ for $16 \mathrm{~h}$ each day increased production of 'Sincerity' geranium cuttings by $30 \%$. Moe (1977) examined the effect of fluorescent light level [estimated at 27, 81, 135, and 189 $\mu \mathrm{mol} \cdot \mathrm{m}^{-2} \cdot \mathrm{s}^{-1}$ PAR using conversions from Thimijan and Heins (1983)] with a 12-h photoperiod on the growth of Campanula isophylla 'Moretti' stock plants in growth chambers. At 300 ppm $\mathrm{CO}_{2}$, cuttings produced per pot increased as light level increased up to 135 $\mu \mathrm{mol} \cdot \mathrm{m}^{-2} \cdot \mathrm{s}^{-1}$, and no difference was observed between 135 and $189 \mu \mathrm{mol} \cdot \mathrm{m}^{-2} \cdot \mathrm{s}^{-1}$. The number of cuttings and DM generally increased as $\mathrm{CO}_{2}$ was supplemented to 900 or $1800 \mathrm{ppm}$, and as temperature increased from $15^{\circ} \mathrm{C}$ to $18^{\circ} \mathrm{C}$. In addition, Moe observed that stock plants grown at a high light level and with supplemental $\mathrm{CO}_{2}$ produced cuttings that rooted earlier and produced more roots than cuttings from stock plants grown at low light level and without $\mathrm{CO}_{2}$ enrichment.

Because vegetative cuttings develop roots and branch more freely than reproductive tissue, flower initiation on stock plants is undesirable. Many specialty annual cultivars are long-day plants. Research by Wang et al. (1999) showed that photoperiods longer than $12 \mathrm{~h}$, or a 4-h night-interruption lighting, initiated early flowering on several specialty-annual species including Scaevola 'New Wonder', Petunia and Verbena 'Tapien' used in our experiments. A challenge for supplemental lighting, therefore, is to increase the light integral without initiating flowering through photoperiod extension. For this reason, in our trials plants were treated with HPS light for an 11-h photoperiod from 6:30 AM to 5:30 PM.

Two trials were undertaken during Winter 1999-2000. One trial was conducted at the Univ. of New Hampshire (UNH), Durham, N.H., and the other was located at Pleasant View Gardens (PVG), in Loudon, N.H. Our objective was to quantify the effect of HPS lighting on both the quantity and quality of vegetative cuttings produced.

\section{Materials and Methods}

$U N H$. The trial was conducted from 8 Nov. 1999 to 31 Jan. 2000 at UNH, in three adjacent glass greenhouse compartments, each $6.1 \times$ $9.1 \mathrm{~m}$. Plants were grown on three $4.6 \times 1.2-\mathrm{m}$ benches, and each bench was separated by a $1.8 \mathrm{~m}$ buffer zone (without HPS). Experimental design was a split-plot, with light level as the main plot, species as the sub-plot randomized within each bench, and each greenhouse compartment was treated as a block.

Within each greenhouse compartment, each bench was randomly assigned one of three light levels: ambient light $\left[6.2 \mathrm{~mol} \cdot \mathrm{m}^{-2} \cdot \mathrm{d}^{-1}\right.$ photosynthetic photon flux $(P P F)]$, ambient light plus $1.6 \mathrm{~mol} \cdot \mathrm{m}^{-2} \cdot \mathrm{d}^{-1} P P F$ from HPS, or ambient plus $2.8 \mathrm{~mol} \cdot \mathrm{m}^{-2} \cdot \mathrm{d}^{-1} P P F$ from HPS. Lamps were installed according to a design provided by P.L. Light Systems Canada (Grimsby, Ontario) using 430-W light fixtures and Phillips 430-W Son Agro bulbs (Phillips Lighting Co., Somerset, N.J). Lights were run for $11 \mathrm{~h}$ beginning before sunrise and ending after sunset each day at 42 or $70 \mu \mathrm{mol} \cdot \mathrm{m}^{-2} \cdot \mathrm{s}^{-1}$ to provide the additional 1.6 and $2.8 \mathrm{~mol} \cdot \mathrm{m}^{-2} \cdot \mathrm{d}^{-1}$ $P P F$.

No shade was placed between benches, and plants on the ambient light benches received 1.4-3.6 $\mu \mathrm{mol} \cdot \mathrm{m}^{-2} \cdot \mathrm{s}^{-1}$ HPS light pollution during this time period each day. Research on photoperiod response of long day plants with HPS found that $<1 \mu \mathrm{mol} \cdot \mathrm{m}^{-2} \cdot \mathrm{s}^{-1}$ was sufficient to induce flower initiation in several long day herbaceous species (Whitman et al., 1998). For most plant species, $3.6 \mu \mathrm{mol} \cdot \mathrm{m}^{-2} \cdot \mathrm{s}^{-1}$ is well below the light compensation point (Hopkins, 1995). We therefore concluded that all plants received sufficient light to perceive an 11-h photoperiod, but that $<4 \mu \mathrm{mol} \cdot \mathrm{m}^{-2} \cdot \mathrm{s}^{-1}$ was unlikely to have a major effect on total photosynthesis on the "ambient light" benches.

On each experimental bench, Apogee model QSO quantum sensors (Apogee Instruments, Logan, Utah) were installed, and on one bench per light level a LI-COR model 
LI-190S quantum sensor (LI-COR, Lincoln, Nebr.) also measured irradiance. All sensors were factory-calibrated immediately before the experiment. Greenhouse air temperature was monitored by an aspirated type-T (copperconstantan) thermocouple, and daily air temperature averaged $19.9 \pm 0.3{ }^{\circ} \mathrm{C}$ [mean \pm one standard deviation (SD)]. Both light level and air temperature readings were recorded every $10 \mathrm{~s}$ and averaged every $15 \mathrm{~min}$ by a Campbell CR10X datalogger with an AM-416 multiplexer (Campbell Scientific, Logan, Utah). Carbon dioxide was monitored using a Qubit model S-151 $\mathrm{CO}_{2}$ analyzer (Qubit Systems, Kingston, Ontario), which was calibrated weekly. Sampled air was channeled through a R\&D Separations Moisture Trap model MT 200-4-D molecular sieve with indicating Drierite (R\&D Separations, Bridgeport, N.J). $\mathrm{CO}_{2}$ levels averaged $398 \mathrm{ppm}$ and there was no difference between day and night $\mathrm{CO}_{2}$ levels.

Four pots of each of four species (Heliotropium, Petunia, Scaevola, and Verbena, Table 1) were randomly positioned on each bench, spaced $0.46 \mathrm{~m}$ on center. All species were grown in MetroMix 560 with ScottsCoir (Scotts-Sierra Horticultural Products Co., Marysville, Ohio). Plants received overhead fertigation with Greencare 17-5-17 or 20-10-20 (Greencare Fertilizers, Chicago) at 150-200 ppm $\mathrm{N}$ depending on species.

Plants were established from rooted cuttings at Pleasant View Gardens and were received at UNH on 1 Nov. 1999. Depending on species, plants were 6-12 weeks old at the beginning of the trial (Table 1). All pots received ambient light $\left(7.6 \mathrm{~mol} \cdot \mathrm{m}^{-2} \cdot \mathrm{d}^{-1} \mathrm{PPF}\right)$ until the start of the experiment on 8 Nov. 1999. The $\mathrm{pH}$ and electrical conductivity (EC) were measured weekly using an Orion model $620 \mathrm{pH}$ meter and model 130 conductivity meter (Orion Research, Beverly, Mass.). The $\mathrm{pH}$ of a saturated medium extract was maintained between 5.5 and 5.9 and EC between $1.5-2.5 \mathrm{mS} \cdot \mathrm{cm}^{-1}$.

The maximum number of viable cuttings (as defined in Table 1) per pot was harvested every $7 \mathrm{~d}$ from 8 Nov. 1999 until 31 Jan. 2000. The fresh mass (FM) of both cuttings and "waste clippings" per pot was also recorded.
"Waste clippings" included plant tissue that was trimmed from stock plants in order to maintain compact growth and encourage lateral branching. These waste clippings represented a component of plant growth, but did not contribute to the overall productivity of the stock plant in terms of cuttings that could be rooted for sale. On 15 Nov. 1999, 20 Dec. 1999, and 31 Jan. 2000, two cuttings per pot were randomly selected and length, stem caliper, FM, and dry mass (DM) were recorded.

In addition, we quantified the effect of lighting stock plants on subsequent rooting of cuttings. On 3 Jan. 2000, 28 cuttings per light treatment were harvested from each species and rooted into 84-cell trays filled with Preforma rooting medium (Preforma, Norwalk, Ohio). At 7, 14, and $21 \mathrm{~d}$ after sticking into media, four cuttings per treatment were evaluated. Number of major roots (defined as longer than $1.0 \mathrm{~cm}$ in length), number of minor roots (defined as $<1.0 \mathrm{~cm}$ in length) and the height of the cutting were recorded.

$P V G$. This trial was conducted from 1 Nov. 1999 to 3 Mar. 2000 in a free-standing, doublepolyethylene greenhouse $(43.9 \times 8.5 \mathrm{~m})$. The greenhouse contained four rows of benches oriented along the length of the greenhouse and separated by aisles. Experimental pots were located only on the interior two benches. Benches were divided into eight experimental zones measuring $3.3 \mathrm{~m}^{2}$, which were separated by buffer zones (without HPS) measuring 2.75 $\mathrm{m}$ along the greenhouse. Plants in four of the randomly assigned zones were grown under ambient light $\left(7.9 \mathrm{~mol} \cdot \mathrm{m}^{-2} \cdot \mathrm{d}^{-1} P P F\right)$. Plants in the remaining four zones were grown under ambient plus $1.9 \mathrm{~mol} \cdot \mathrm{m}^{-2} \cdot \mathrm{d}^{-1} P P F$ HPS using $430-\mathrm{W}$ fixtures at $48 \mu \mathrm{mol} \cdot \mathrm{m}^{-2} \cdot \mathrm{s}^{-1}$ for an $11-\mathrm{h}$ photoperiod. Benches were not shaded between zones, and plants on the "ambient" benches received between $0.94-1.88 \mu \mathrm{mol} \cdot \mathrm{m}^{-2} \cdot \mathrm{s}^{-1} \mathrm{HPS}$ light pollution during the photoperiod each day. Greenhouse air temperature averaged 20.4 $\pm 1.0^{\circ} \mathrm{C}$ (mean $\pm 1 \mathrm{SD}$ ), and the same light and temperature sensing equipment was used as at UNH.

Within each experimental zone, 3 pots of each of 10 cultivars (Table 1 ) were randomly positioned, and were spaced at $0.46 \mathrm{~m}$ on center. All species were grown in MetroMix
560 with ScottsCoir (Scotts-Sierra Horticultural Products Co., Marysville, Ohio). Plants received overhead fertigation with a rotation of 15-5-15, 15-2-20, and 15-0-15 (ScottsSierra Horticultural Products Co.) at 150-200 ppm $\mathrm{N}$ depending on species.

The maximum number of viable cuttings (as defined in Table 1) per pot were harvested and recorded every $7 \mathrm{~d}$ from 12 Nov. 1999 until 7 Jan. 2000, after which cuttings were harvested every $14 \mathrm{~d}$ until the conclusion of the trial on 3 Mar. 2000. On 12 Nov. and 10 Dec. 1999, 7 Jan., 4 Feb., and 3 Mar. 2000, two cuttings per pot were randomly selected and their length, stem caliper, FM, and DM were recorded.

The average number of cuttings and FM per stock container per week was calculated by dividing the final accumulated yield and mass for each treatment by the number of weeks duration of each experiment. Analysis of variance (ANOVA) was performed on the number of cuttings and FM per stock container per week and also on cutting-quality parameters, using the GLM module in Systat 9 for Windows (SPSS, Chicago). Type III sums of squares were used to test hypotheses, and Tukey's honestly significant difference (HSD) multiple comparison test was used to compare treatment means.

\section{Results}

There was a gradual increase in cutting production over time at UNH with supplemental lighting compared to ambient. There was a significant interaction effect between light and species on number of cuttings, and Heliotropium showed less response than the three other species (Table 2). Although the mean number of cuttings tended to increase between the 1.6 and $2.8 \mathrm{~mol} \cdot \mathrm{m}^{-2} \cdot \mathrm{d}^{-1} P P F$ HPS levels for Petunia, Scaevola, and Verbena, there was insufficient replication to show statistically significant differences between the two HPS levels (Fig. 1A). In relative terms, using production under ambient light as a standard, Scaevola showed the most response to HPS (51\% increase in cutting number with an additional $1.6 \mathrm{~mol} \cdot \mathrm{m}^{-2} \cdot \mathrm{d}^{-1} P P F$ from HPS and $73 \%$ increase with an additional 2.8

Table 1. Species grown at UNH or PVG, and parameters used to define a viable cutting.

\begin{tabular}{|c|c|c|c|c|c|c|c|}
\hline \multirow[b]{2}{*}{ Species and cultivar ${ }^{2}$} & \multirow[b]{2}{*}{$\begin{array}{c}\text { Date of } \\
\text { transplant }\end{array}$} & \multirow[b]{2}{*}{$\begin{array}{l}\text { Cuttings } \\
\text { per pot }\end{array}$} & \multirow[b]{2}{*}{$\begin{array}{l}\text { Pot diam } \\
\qquad(\mathrm{cm})\end{array}$} & \multicolumn{4}{|c|}{ Parameters used to define a viable cutting ${ }^{\mathrm{y}}$} \\
\hline & & & & $\begin{array}{c}\text { Leaf } \\
\text { arrangement }\end{array}$ & $\begin{array}{l}\text { No. of } \\
\text { nodes }^{\mathrm{x}}\end{array}$ & $\begin{array}{c}\text { Caliper } \\
(\mathrm{mm})\end{array}$ & $\begin{array}{c}\text { Fresh mass } \\
(\mathrm{g})\end{array}$ \\
\hline Argyranthemum 'Summer Melody' & 20 Sept. & 2 & 20.3 & Alternate & $4-6$ & $\geq 1.90$ & $\geq 0.60$ \\
\hline Heliotropium arborescens 'Atlantis' & 20 Sept. & 3 & 20.3 & Alternate & $4-5$ & $\geq 1.55$ & $\geq 0.25$ \\
\hline Lantana hybrid 'Patriot Firewagon' & 9 Aug. & 4 & 25.4 & Opposite & 1 or 2 & $\geq 1.35$ & $\geq 0.40$ \\
\hline Aloysia triphylla (Lemon Verbena) & 20 Sept. & 3 & 20.3 & Opposite & 2 & $\geq 0.65$ & $\geq 0.09$ \\
\hline Impatiens New Guinea hybrid 'Pedro' & 20 Sept. & 2 & 15.2 & Opposite & 2 or 3 & $\geq 2.25$ & $\geq 0.60$ \\
\hline Osteospermum 'Lemon Symphony' & 20 Sept. & 4 & 25.4 & Alternate & 4 & $\geq 2.45$ & $\geq 0.70$ \\
\hline Scaevola aemula 'New Wonder' & 9 Aug. & 4 & 25.4 & Alternate & 4 & $\geq 2.35$ & $\geq 0.60$ \\
\hline Petunia hybrid 'Supertunia Blue Wren' & 20 Sept. & 4 & 25.4 & Alternate & 4 & $\geq 2.20$ & $\geq 0.50$ \\
\hline Petunia hybrid 'Supertunia Sun Snow' & 20 Sept. & 4 & 25.4 & Alternate & 4 & $\geq 1.85$ & $\geq 0.30$ \\
\hline Verbena hybrid 'Tapien Soft Pink' & 20 Sept. & 4 & 25.4 & Opposite & 1 or 2 & $\geq 0.65$ & $\geq 0.07$ \\
\hline
\end{tabular}

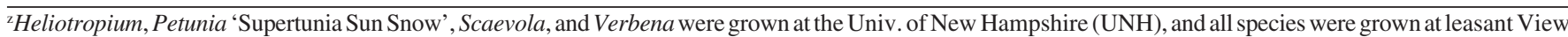
Gardens (PVG).

yParameters were defined through discussion with commercial horticulture staff at PVG, and measurements of a range of commercially acceptable and unacceptable cuttings before the experiment.

${ }^{\mathrm{x}}$ Number of nodes with leaves at least half-expanded. 
Table 2. Analysis of variance summary for cutting production at the Univ. of New Hampshire (UNH) and Pleasant View Gardens (PVG).

\begin{tabular}{lccc}
\hline & $\begin{array}{c}\text { Avg no. of } \\
\text { cuttings per pot } \\
\text { per week }(\mathrm{UNH})\end{array}$ & $\begin{array}{c}\text { Avg no. of } \\
\text { cuttings per pot } \\
\text { per week }(\mathrm{PVG})\end{array}$ & $\begin{array}{c}\text { Avg total fresh wt } \\
\text { (cuttings and waste clippings) } \\
\text { per pot per week }(\mathrm{UNH})\end{array}$ \\
\hline Light & NS $(P=0.06)$ & $*$ & NS $(P=0.21)$ \\
Species & $* * *$ & $* * *$ & $* * *$ \\
Light $\times$ species & $*$ & $* *$ & $* * *$ \\
\hline
\end{tabular}

$\overline{N s, * * *, * * * *}$ Not statistically significant, and significance at the $0.95,0.99$, and 0.999 levels, respectively.

$\mathrm{mol} \cdot \mathrm{m}^{-2} \cdot \mathrm{d}^{-1} P P F$ from HPS). In terms of absolute increase in number of cuttings (Fig. 1A), Petunia and Verbena had the greatest increase by over 5 and 10 cuttings per pot per week at the two HPS levels compared with production under ambient light. Petunia and Verbena also produced more cuttings under ambient light compared with Scaevola and Heliotropium.

Fresh mass increased at the two HPS levels compared with growth under ambient light at $\mathrm{UNH}$, although there was no significant difference for Heliotropium (Fig. 1B). Of the four species, FM increased most for Scaevola in both relative and absolute terms under HPS
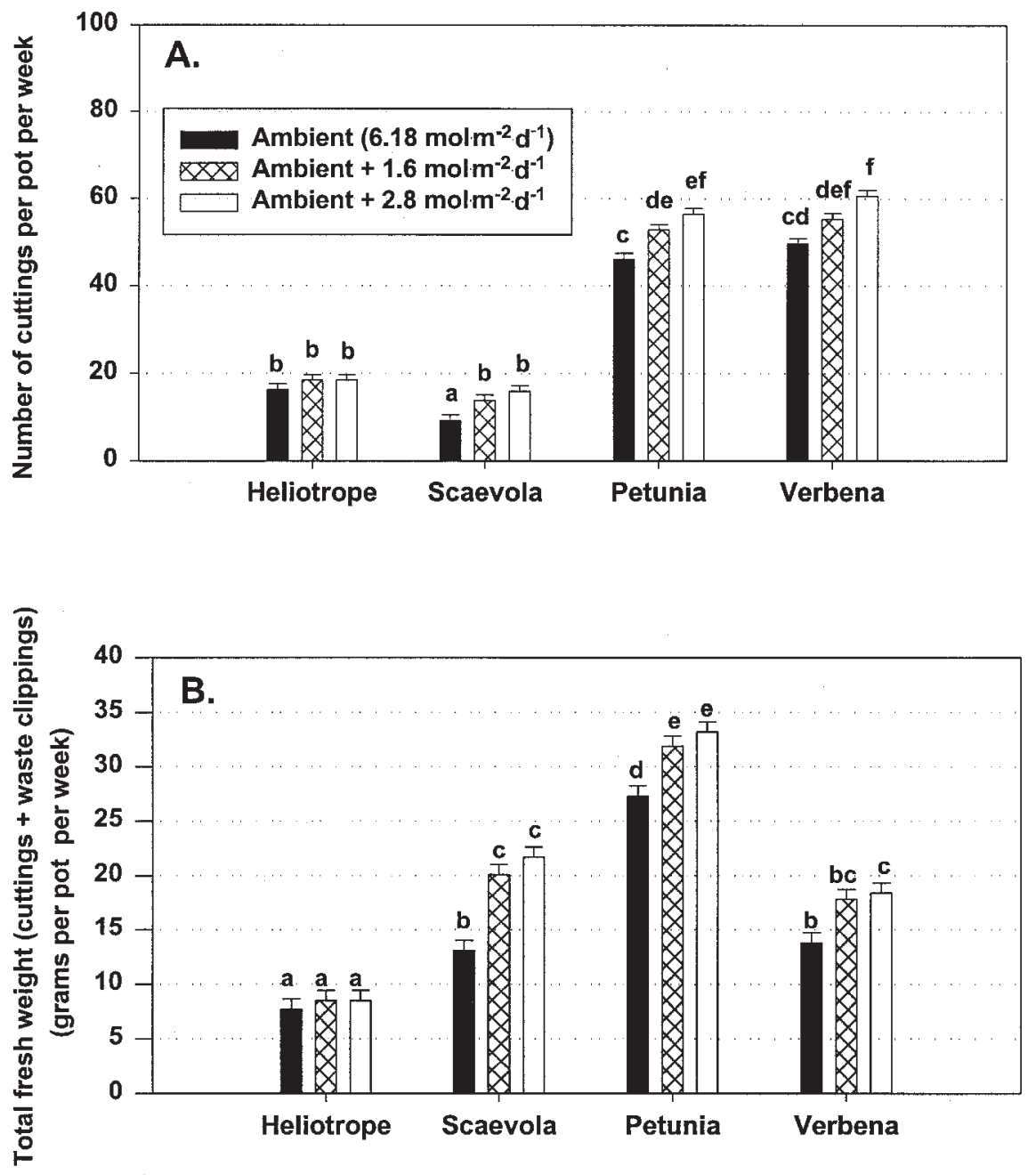

Fig. 1. (A) Number of cuttings per pot per week averaged from Nov. 1999 to Feb. 2000 under three light levels at the Univ. of New Hampshire (error bars $\pm 1 \mathrm{sE}$ ). (B) Total fresh weight in grams per pot per week (from combined viable cuttings and waste clippings, error bars (1 SE). Bars in graphs (A) or (B) that share the same letter are not significantly different from each other at the 95\% level using Tukey's HSD multiple comparison test. for Scaevola, Petunia 'Sun Snow', and Osteospermum. For these four species, between 2.8 and 6.7 additional cuttings were produced under HPS per pot per week. Verbena had less response to HPS at PVG than was observed at UNH.

In both the UNH and PVG trials, the ANOVA of cutting length, stem caliper, FM and DM indicated that the main effects of light and the light $\times$ species interactions were nonsignificant at the $P<0.05$ level. Additionally, at UNH, cuttings of Heliotropium, Scaevola, Petunia, and Verbena from all light treatments were evaluated during the vegetative propagation phase. There was no significant difference in the number of major or minor roots, or the height of the rooted cutting between the three light treatment levels.

\section{Discussion}

Growth of each of the four species (Heliotropium, Scaevola, Petunia 'Sun Snow', and Verbena) under ambient light conditions was similar at the two locations. The main difference in performance of species at the two locations was Verbena, which at PVG had only a $4 \%$ increase (nonsignificant) in cutting production in response to HPS compared with $12 \%$ at $\mathrm{UNH}$ (with an additional $1.6 \mathrm{~mol} \cdot \mathrm{m}^{-}$ ${ }^{2} \cdot \mathrm{d}^{-1} P P F$ from HPS). Cutting production for Heliotropium was not significantly affected by light level at either location, whereas Scaevola and Petunia 'Sun Snow' consistently showed an increase in cutting number with addition of HPS. Osteospermum and Aloysia also showed a significant cutting production response to light level at PVG. Although there was no significant difference in cutting production with an additional 1.6 vs. $2.8 \mathrm{~mol} \cdot \mathrm{m}^{-2} \cdot \mathrm{d}^{-1} P P F$ from HPS at UNH, trends in the mean cutting numbers (Fig. 1) suggest that additional experimentation could be useful to identify the optimum light level for cutting production of species including Scaevola, Petunia 'Sun Snow', and Verbena.

Several factors differed between the locations. The species mix at PVG included species that generally grew slower than the four species grown at UNH. Carbon dioxide level can affect cutting production and quality (Moe, 1977), and although $\mathrm{CO}_{2}$ was not measured at PVG, $\mathrm{CO}_{2}$ may have been more limiting than at UNH because of the higher plant density and fewer air exchanges in the doublepolyethylene greenhouse construction at PVG. Despite higher light transmission through the glass covering at UNH, ambient light level was lower than at PVG $\left(6.2 \mathrm{vs} .7 .9 \mathrm{~mol} \cdot \mathrm{m}^{-2} \cdot \mathrm{d}^{-1}\right)$. Given the higher ambient light at PVG than $\mathrm{UNH}$, similar percentage increases $(24 \%$ to $27 \%$ ) in light were contributed by the additional 1.6 and $1.9 \mathrm{~mol} \cdot \mathrm{m}^{-2} \cdot \mathrm{d}^{-1} P P F$ from HPS at UNH and PVG relative to the total amount of light.

Cutting response to HPS varied considerably between species and cultivars, and showed the need for growers to trial each cultivar to check whether HPS lighting is effective. The absence of observed differences in initial quality of cuttings, and their subsequent rooting, 


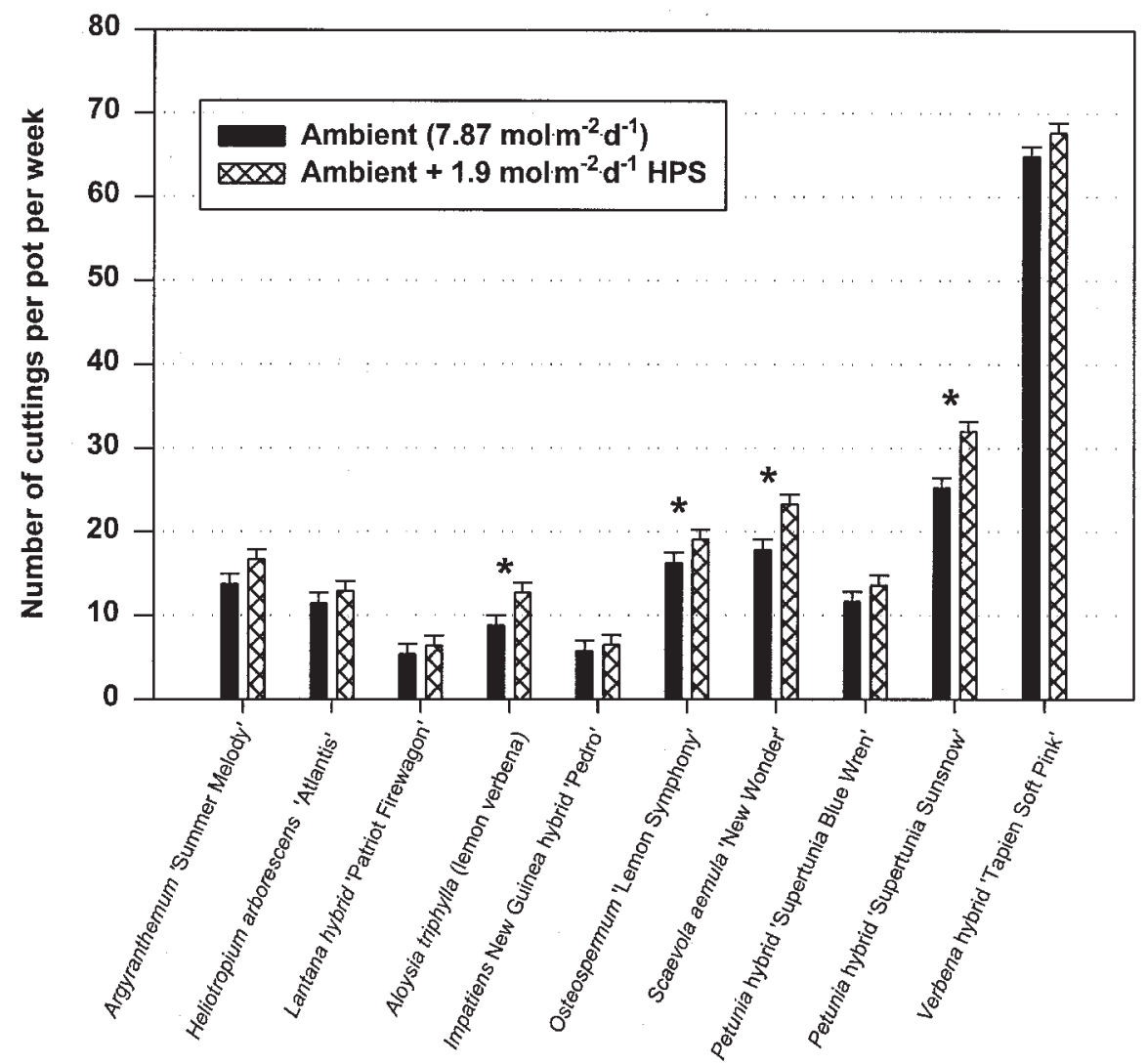

Fig. 2. Number of cuttings per pot per week for 10 species under two light levels, averaged from Nov. 1999 to Mar. 2000 at Pleasant View Gardens (least-square means of four replicates per light level, error bars $\pm 1 \mathrm{SE})$. Species that had a statistically significant response to light using ANOVA are represented with the ${ }^{*}$ symbol.

may have been because the ambient light treatment was not low enough to affect stored carbohydrate level and internode elongation of cuttings. In our trials the primary effect of HPS was measured on cutting production num- bers and overall FM production, but cutting quality may be affected for other species, or

Marsh and Singh (1994) and Heins and Carlson (1987) both developed models for under darker ambient light conditions. evaluating an investment in supplemental lighting for greenhouse production, which is an important next step in analyzing results for stock plants. Our subsequent research will apply these models to specialty annual stockplant production, in order to calculate the increase in cuttings per pot per week or cuttings per $\mathrm{m}^{2}$ per week necessary to justify investment in an HPS lighting system.

\section{Literature Cited}

Heins, R.D. and W.H. Carlson. 1987. SON takes the guesswork out of calculating supplemental greenhouse lighting costs. BPI News, Feb. 1987:10-12.

Hopkins, W.G. 1995. Introduction to plant physiology. Wiley, New York, p. 254.

Marsh, L. and S. Singh. 1994. An economic analysis of supplemental lighting for commercial greenhouse rose production. Appl. Eng. in Agr. 10:801-809.

Moe, R. 1977. Effect of light, temperature and $\mathrm{CO}_{2}$ on the growth of Campanula isophylla stock plants and on the subsequent growth and development of their cuttings. Scientia Hort. 6:129-141.

Thimijan, R. and R.D. Heins. 1983. Photometric, radiometric, and quantum light units of measure: A review of procedures for interconversion. HortScience 18:818-822.

Tsujita, J.M. and P.M. Harney. 1978. The effects of Florel and supplemental lighting on the production and rooting of geranium cuttings. J. Hort. Sci. 53(4):349-350.

Wang, S., W. Carlson, and R.D. Heins. 1999. Pushing proven winners. Greenhouse Grower, Mar. 1999:115-118.

Whitman, C.M., R.D. Heins, A.C. Cameron, and W.H. Carlson. 1998. Lamp type and irradiance level for daylength extensions influence flowering of Campanula carpatica 'Blue Clips', Coreopsis grandiflora 'Early Sunrise', and Coreopsis verticillata 'Moonbeam'. J. Amer. Soc. Hort. Sci. 123:82-807. 